\title{
20. HEAT FLOW AND THERMAL HISTORY OF THE EXMOUTH PLATEAU1
}

\author{
Michael Swift, ${ }^{2}$ Ron Boyd,${ }^{3}$ David O'Brien, ${ }^{4}$ and Juan Lorenzo ${ }^{5}$
}

\begin{abstract}
Heat-flow levels of 79 and $64 \mathrm{~mW} / \mathrm{m}^{2}$ have been determined in two holes at ODP Leg 122 Sites 762 and 763, over the Exmouth Plateau. These two heat-flow values are compared with independently derived heat-flow measurements made previously near the drill sites. There is generally a poor correspondence between the heat flow measured at the surface to that measured at intermediate depths of approximately $100 \mathrm{mbsf}$ and that derived for greater depths. Heat flow appears to increase with depth. This is possibly due to experimental error, or it may be due to complex mechanisms of heat transfer in the sediments. Thermal geohistory analysis is undertaken at each site, and these results and the heat-flow data are used to draw implications for the study of thermal history of the region. Most notably, sedimentation has disturbed the near-surface heat flow and horizontal temperature gradients may be causing natural convection of the pore fluids.
\end{abstract}

\section{INTRODUCTION}

The surface heat-flow pattern for the Exmouth Plateau region (Fig. 1), offshore northwest Australia, has been well defined (Swift, 1990). The average surface heat flow is 59 $\mathrm{mW} / \mathrm{m}^{2}$, which is a typical level for continental crust. Overall the areal variation in heat flow is rather smooth, with a gradual trend from high heat flow, of the order of $100 \mathrm{~mW} / \mathrm{m}^{2}$, from a confined region in the southeast, to average heat-flow values on the rest of the plateau. It is within this average background heat flow that a single region of low heat flow is recorded. The confined heat-flow high and the heat-flow low are the only major heat-flow anomalies (relative to the average heat flow) for the region.

As surface heat-flow patterns are an expression of subsurface thermal processes (i.e., diffusion, convection, and internal heat generation), the surface heat-flow pattern can be interpreted in order to describe the dominant methods of heat transfer in the crust. The surface heat-flow level within the low heat-flow region $\left(20 \mathrm{~mW} / \mathrm{m}^{2}\right)$ is less than the base crustal level $\left(25 \mathrm{~mW} / \mathrm{m}^{2}\right)$, which indicates that natural (thermally driven) pore-fluid convection together with conduction is probably the main means of heat transfer in the continental crust within the region (Swift, in press). Heat-flow measurements from two Ocean Drilling Program (ODP) Leg 122 holes over the Exmouth Plateau were designed to test if heat flow varies with depth or laterally, as might be expected in a convective pore-fluid regime.

Surface heat flow had been measured near the drill sites using conventional deep-sea measurement techniques (Choi et al., 1987). Further, heat flow at deep levels was also determined from a numerical thermal geohistory analysis at two nearby oil exploration wells (Eendracht and Vinck, which

\footnotetext{
1 von Rad, U., Haq, B. U., et al,, 1992. Proc. ODP, Sci. Results, 122: College Station, TX (Ocean Drilling Program).

2 Bureau of Mineral Resources, Canberra, ACT, 2601, Australia. (Present address: A.G.L. Petroleum, G.P.O. Box 1010, Brisbane, QLD, 4001, Australia.)

${ }^{3}$ Dalhousie University, Halifax, Nova Scotia B3H 3J5, Canada. U.S.A.

${ }^{4}$ Hawaii Institute of Geophysics, 2525 Correa Road, Honolulu, HI 96822 ,

5 Lamont-Doherty Geological Observatory, Columbia University, Palisades, NY 10964, U.S.A.
}

correspond to Sites 762 and 763 , respectively). Consequently, the ODP sites provided an opportunity to measure heat flow at intermediate depths at these locations.

The limited number of temperature measurements at Sites 762 and 763 makes it difficult to quantify or greatly modify existing thermal models for the region. However, it is necessary to discuss this important data set in light of the varying thermo-tectonic models and preexisting heat-flow data set of the Exmouth Plateau region. The aim of this paper is to examine the hypothesis of natural pore-fluid convection, explain the lateral change in the vertical temperature, from high in the east to low in the western central part of the Exmouth Plateau, and develop an understanding of why the southern Northwest Shelf has such a high heat-flow level. To do this, heat-flow data from Sites 762 and 763 were incorporated into the existing data set, and the results are discussed as follows.

\section{PREVIOUS GEOTHERMAL DATA AND THERMAL MODELS}

Numerous heat-flow determinations have been made on and about the Exmouth Plateau region prior to those described here. A map of the existing heat-flow data is given in Figure 1. Prior to 1982, only one marine heat-flow value was reported from the Exmouth Plateau: $61.1 \mathrm{~mW} / \mathrm{m}^{2}$ from a station located on the northwest flank of the plateau in a water depth of about $1800 \mathrm{~m}$ (Anderson et al., 1977). Von Herzen and Langseth (1965) and Langseth and Taylor (1967), in studies of the lower slope and abyssal plains north of the Exmouth Plateau, reported a number of heat-flow values in the range of $45-96 \mathrm{~mW} / \mathrm{m}^{2}$.

Cull and Conley (1983) evaluated the temperature gradients from a number of offshore wells and estimated that heat-flow values on the continental shelf were in the range of 75-119 $\mathrm{mW} / \mathrm{m}^{2}$. From these widespread data it was postulated that the plateau proper has an average heat-flow level in the order of $60 \mathrm{~mW} / \mathrm{m}^{2}$ and that the southern areas of the Northwest Shelf are characterized by high heat flow, in the range of $70-120 \mathrm{~mW} / \mathrm{m}^{2}$. Burne and Kantsler's (1977) detailed geothermal study indicates temperature gradients of approximately $30^{\circ} \mathrm{C} / \mathrm{km}$ on the Northwest Shelf. Nicholas et al.'s (1980) compilation of uncorrected geothermal gradients for the Northwest Shelf using oil exploration well data illustrates a general trend of high geothermal gradients for the region. The 


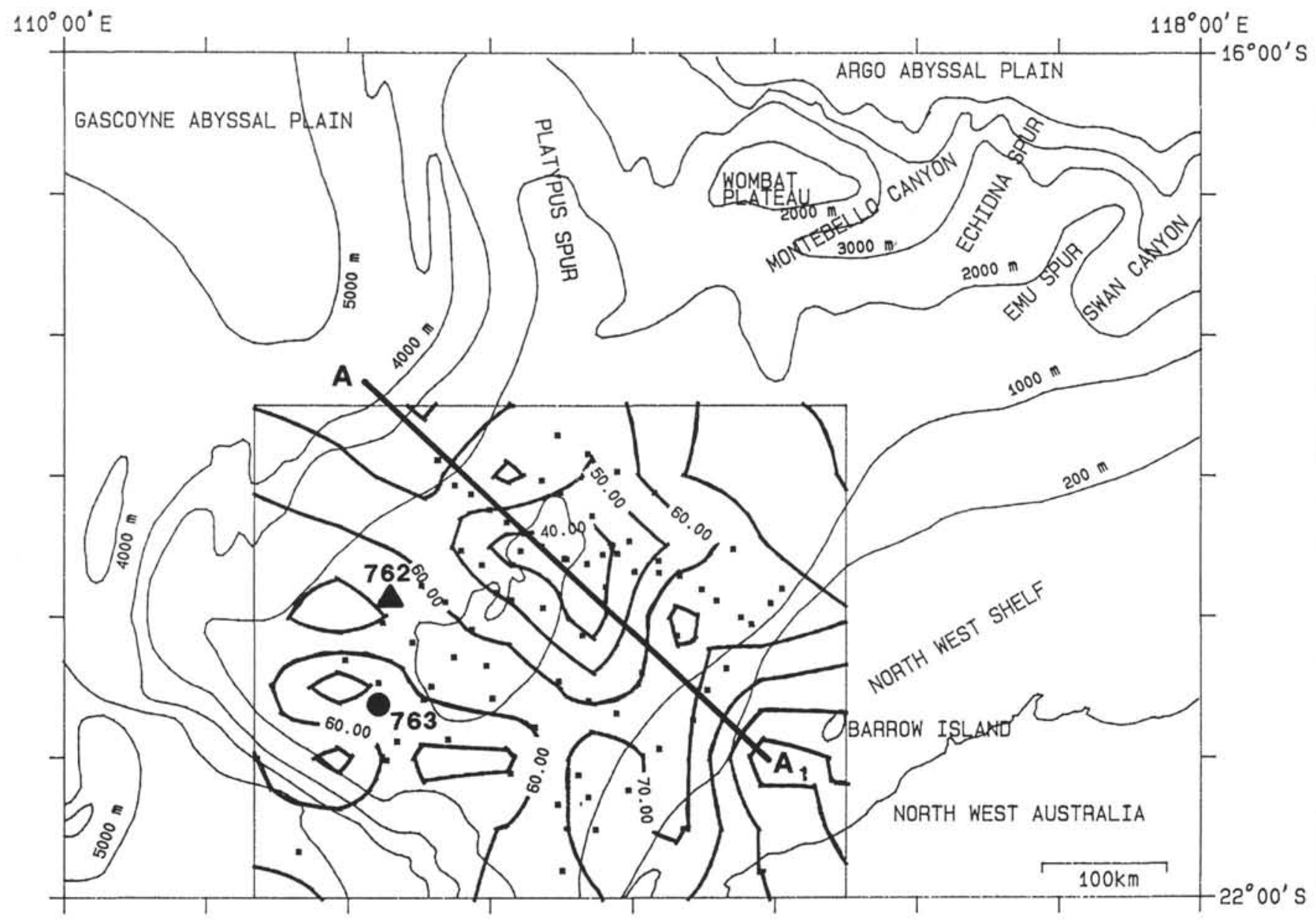

Figure 1. Surface heat-flow map of the Exmouth Plateau. Heat-flow contour values in $\mathrm{mW} / \mathrm{m}^{2}$ for data points shown as dots. The locations of Sites 762 and 763 are coincident with the Eendracht exploration well and heat-flow site FRHF42 (Site 762) and Vinck exploration well and heat-flow site FRHF45 (Site 763) (Swift, 1990). Section A-A is given in Figure 2.

geothermal gradient on the eastern Northwest Shelf averages $35^{\circ} \mathrm{C} / \mathrm{km}$, whereas data from exploration wells on the $\mathrm{Ex}$ mouth Plateau indicate that geothermal gradients are about $23^{\circ} \mathrm{C} / \mathrm{km}$ on the Exmouth Plateau (Barber, 1984). Thus, the well data show that there is a lateral variation in the geothermal gradient across the plateau.

Thermal maturity data (vitrinite reflectance values) from a number of wells have been used to derive first-order paleoheat-flow levels. In general the vitrinite reflectance levels for the wells on the Northwest Shelf are too low, if a constant (present-day) geothermal gradient since burial is assumed (Kopsen and McGann, 1985). In other words, there appears to have been a rise in the geothermal gradient since the Tertiary.

Kopsen and McGann (1985) explained this discrepancy by assuming a constant thermal gradient of $15^{\circ} \mathrm{C} / \mathrm{km}$ until $13 \mathrm{Ma}$, which then increased to $30^{\circ}-40^{\circ} \mathrm{C} / \mathrm{km}$ until the present day. The idea of a late heat pulse was first suggested by Cook and Kantsler (1980), who showed that vitrinite reflectance profiles are not disturbed by the pre-Cretaceous uplift and erosion of $2000 \mathrm{~m}$ of sediment; that is, it appears that the vitrinite reflectance values in the pre-Cretaceous sediments were set by thermal conditions in the Tertiary. Cook et al. (1985) reported the same phenomena: "to explain the relatively low present day vitrinite reflectance values near the top of the Triassic, the (past) geothermal gradients must have been much less than the present day gradients during the Mesozoic and early Tertiary, but must have undergone a major rise in the late Tertiary." This contradicts all the tectonically derived thermal models for passive margins, which imply higher heat flows, and implicitly higher geothermal gradients, in the past (Sleep, 1971; McKenzie, 1978). In 1986 the Australian Bureau of Mineral Resources collected a suite of 35 surface heat-flow measurements over the Exmouth Plateau (see Choi et al., 1987). This data set highlighted the heat-flow low in the center of the plateau and gave rise to the hypothesis that natural pore-fluid convection within the sediments was occurring on the regional scale in the plateau sediments (Swift et al., 1988).

The following year, the Australian National University recorded a further 51 heat-flow measurements. During this collection phase, surface heat-flow measurements were obtained directly over designated Sites 762 and 763 . The heatflow levels were 72 and $41 \mathrm{~mW} / \mathrm{m}^{2}$, respectively (Swift, 1990).

The regional setting of the Exmouth Plateau is shown in Figure 1. The plateau is believed to be underlain by Precambrian basement, capped by faulted and gently folded Permian to Lower Cretaceous clastic and detrital sediments, with a thin cover of Tertiary deep-water carbonates. The sedimentary column over basement contains classic passive margin prerift, rift, and postrift sequences. The structure of what was to become the Exmouth Plateau was initiated by rifting during 

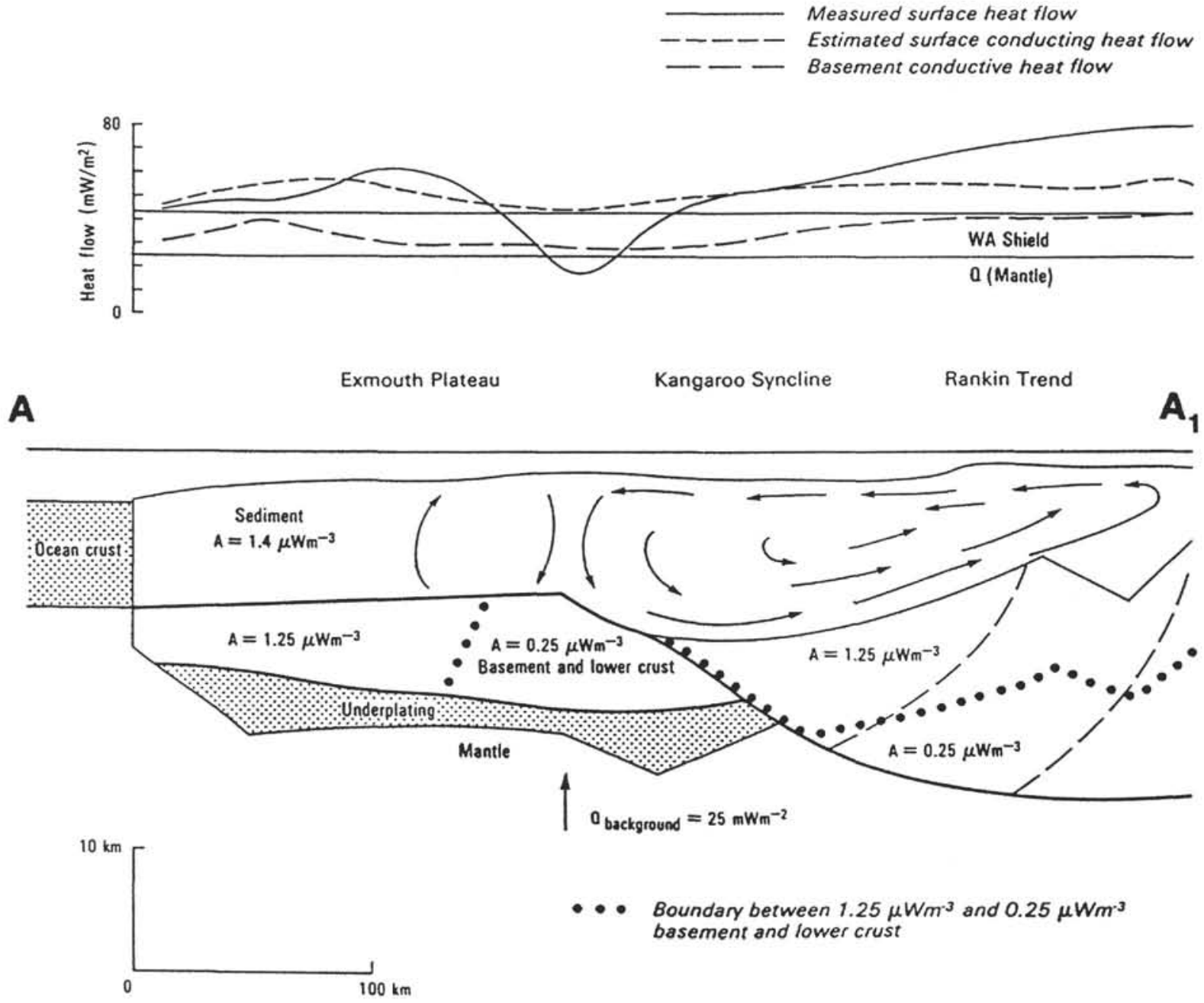

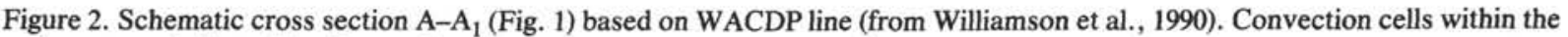
sediment are indicated by flow paths.

the Triassic and Jurassic, prior to seafloor spreading in the Argo Abyssal Plain (Jurassic) and Gascoyne and Cuvier abyssal plains (Early Cretaceous).

Thermal models for the Exmouth Plateau, whether the rifted margins are related to an interarch basin in a dual-axis system (Veevers and Cotterill, 1978, 1979) or an upper plate margin formed during delamination of the crust (Lister et al., 1986; for which Voorhoeve and Houseman, 1988, have developed a thermal model), have been attempted by Swift (1990). The conclusion was that the heat-flow regime is so greatly disturbed by natural pore-fluid convection that thermal models of margin development are impossible to test. Note that in Figure 1 there is no correlation between the heat-flow trends and the margins. The driving force for the natural pore-fluid convection is the regional structure of the plateau (Fig. 2), which was discussed at some length by Williamson et al. (1990). Numerical modeling results that support natural porefluid convection are given in Swift (in press).

\section{RESULTS AND DISCUSSION}

Five downhole temperature measurements were made at Sites 762 and 763 , between depths of 50 and $150 \mathrm{~m}$ below seafloor (mbsf). The temperature records for each run, two at Site 762 and three at Site 763 , are given in Figures 3 through 7 . With the exception of the temperature measure- ment at $147.4 \mathrm{mbsf}$ at Site 763 (Fig. 7), the quality of the temperature records appears to be good, and a reliable equilibrium temperature can be derived by judicious filtering. Temperatures measured were extrapolated to equilibrium using the method described in Bullard (1954); these values are listed in Table 1 . The resolution of the thermal probe is about $0.05^{\circ} \mathrm{C}$, and the corresponding accuracy of the equilibrium temperatures is about $\pm 0.1^{\circ} \mathrm{C}$. The cause of minor fluctuations in the temperature records when the temperature probe is in the sediment is unknown. It may be due to minor up and down movements of the probe due to insufficient heave compensation.

Thermal conductivity measurements were derived at close intervals on the cores taken at each site (Haq, von Rad, O'Connell, et al., 1990, p. 273, fig. 40, and p. 342, fig. 35). Thermal conductivity measurements were made by the needle probe method (Von Herzen and Maxwell, 1959); the error estimate is $\pm 5 \%$. The expected, generally gradual increase in thermal conductivity with depth makes it necessary to integrate the thermal resistivity and cross-plot the temperature, from which the slope of the line is the vertical conductive heat flow. The Bullard plot of temperature vs. thermal resistance is given in Figure 8. The heat flow for Site 762 is $79 \mathrm{~mW} / \mathrm{m}^{2}$ and for Site 763 is $64 \mathrm{~mW} / \mathrm{m}^{2}$. The error of the heat-flow values derived from Figure 8 is about $25 \%$ for Site 762 and $15 \%$ for 


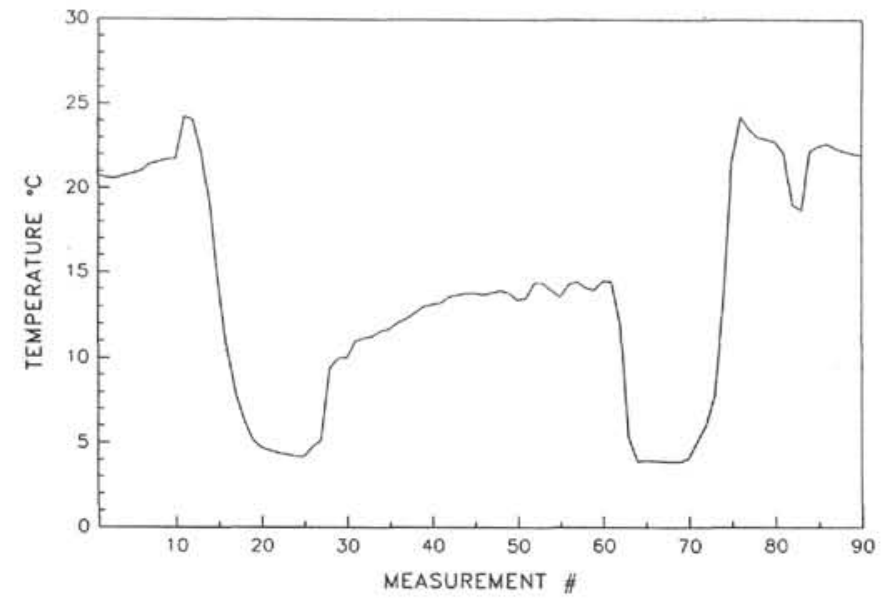

Figure 3. Record for temperature run at Site 762 at a depth of 99.4 mbsf.

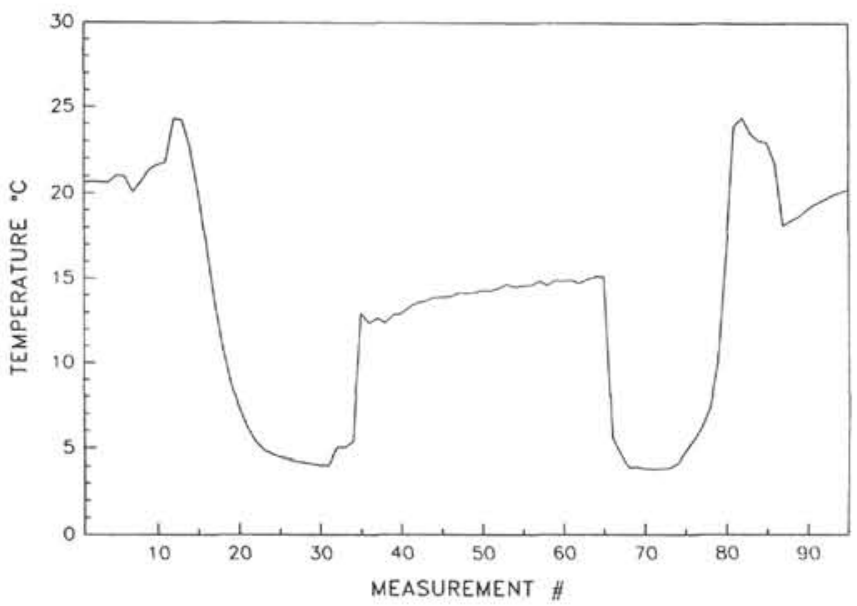

Figure 4. Record for temperature run at Site 762 at a depth of 156.4 mbsf.

Site 763. These levels can be compared to the measured heat-flow levels of 72 and $41 \mathrm{~mW} / \mathrm{m}^{2}$, respectively.

Another means to compare heat-flow levels is by the use of thermal geohistory analysis. Thermal geohistory is a method whereby structural, subsidence, maturation, and temperature histories can be calculated from a stratigraphic column (Guidish et al., 1985). The major importance of this technique is in the study of the subsurface heat-flow results from Sites 762 and 763 and the Eendracht and Vinck exploration wells.

The method used in this paper is a numerical scheme based on Hutchison (1985). This scheme is readily adapted to complex geological cases, such as those found on this passive margin. The geohistory plots for the four wells of this study and a relevant discussion are given in the following sections.

\section{Eendracht Exploration Well}

The thermal geohistory plot for the Eendracht exploration well (Fig. 9) shows the characteristic pull-up in the isotherms as the sediment layer thickens. This is due largely to the lower thermal conductivity of the sediments relative to the basement rocks, and hence the ability of the sediment to support a relatively higher temperature gradient. The temperature profile of this well (and all subsequent wells) is based on the present-day heat-flow calculation from the bottom-hole tem-

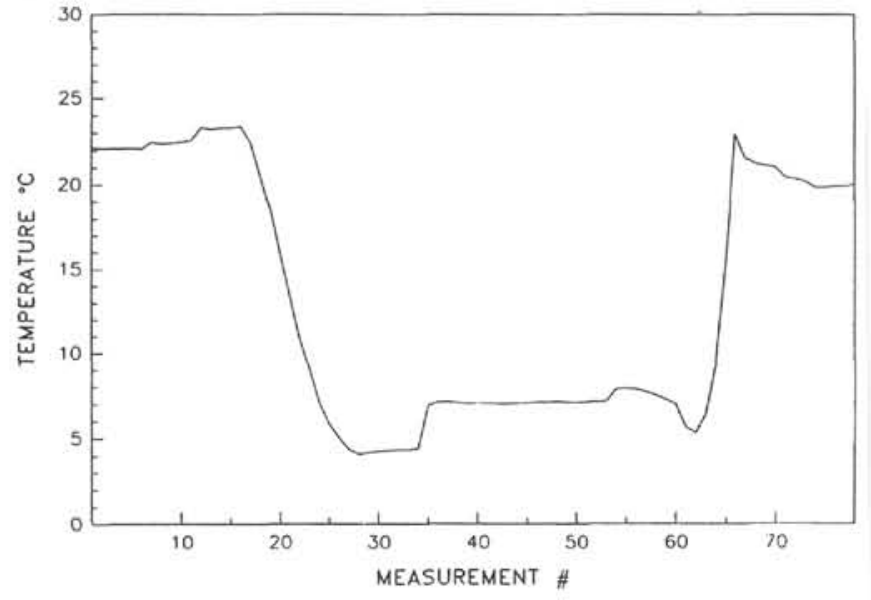

Figure 5. Record for temperature run at Site 763 at a depth of 52.4 mbsf.

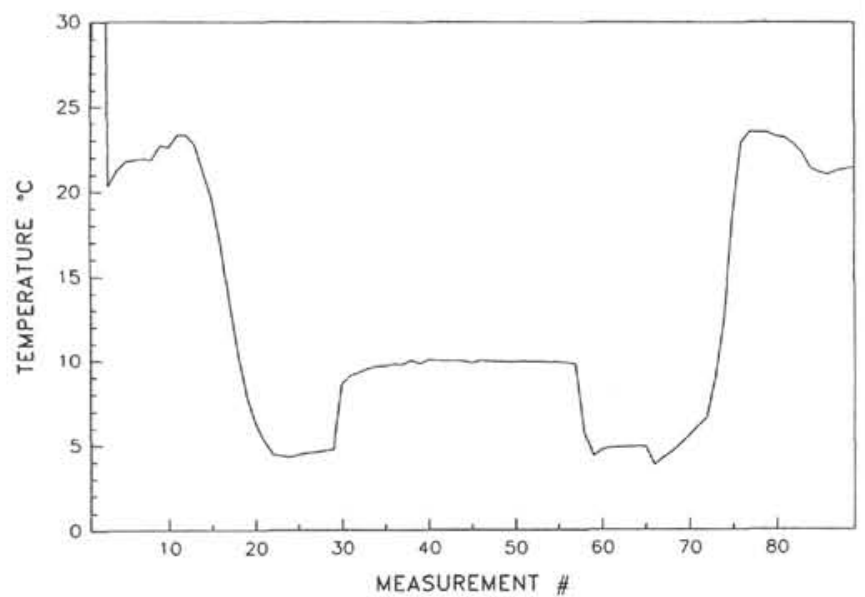

Figure 6. Record for temperature run at Site 763 at a depth of 90.4 mbsf.

perature (BHT). The modeling has assumed a constant heat flow at this level for all time. This makes it possible to quantify the thermal anomaly in the temperature and heat flow due to the geological processes of basin formation. The discrepancy between the measured and the calculated temperatures corresponding to the BHT depth reflects the level of this thermal anomaly. The assumption of constant basal heat flow with time at the present-day level is clearly an oversimplification, as heat flows should be higher at the time of basin formation.

However, because of the errors due to the assumed thermal conductivity profile and the BHT, it would be difficult to truly determine the present-day temperature profile even if the paleo-heat flow was better known. Where the thermal geohistory analysis is useful is in modeling the relative temperature changes in the temperature profile that result from the effects of sedimentation, compaction, uplift, erosion, fluid flow, and most importantly the change in surface heat flow relative to basement heat flow.

The most sensitive way to look at the thermal anomalies associated with basin formation is via the calculated heat flow, the results of which are presented in Figure 10. For this location the heat flow at basement depth was calculated to be $96 \mathrm{~mW} / \mathrm{m}^{2}$. Note the massive reduction in the surface heat flow due to the high sedimentation rate from 250 to $210 \mathrm{Ma}$. The difference between basement and surface heat flow illus- 


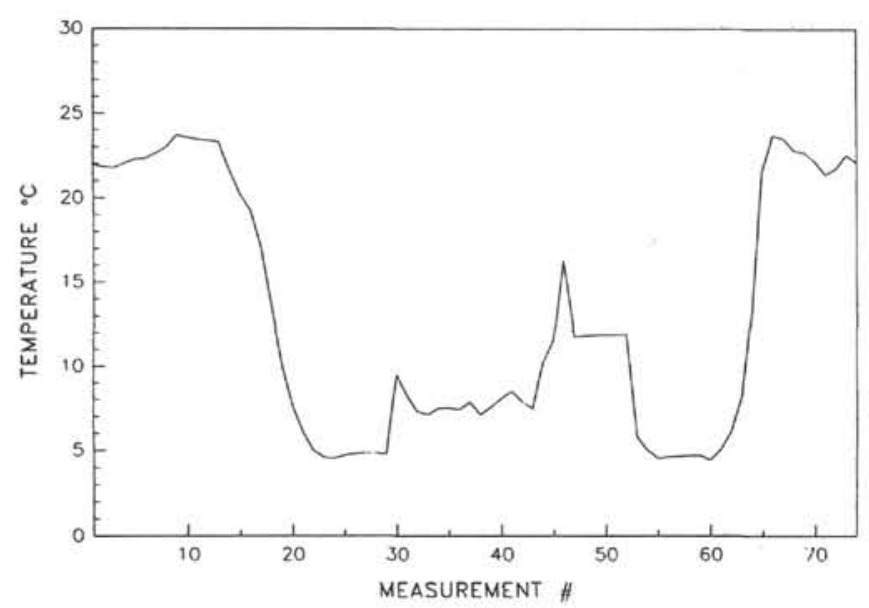

Figure 7. Record for temperature run at Site 763 at a depth of 147.4 mbsf.

Table 1. Heat-flow levels at coincident points on the Exmouth Plateau.

\begin{tabular}{lcccc}
\hline \multicolumn{1}{c}{ Site } & $\begin{array}{c}\text { Depth } \\
(\mathrm{mbsf})\end{array}$ & $\begin{array}{c}\text { Temperature } \\
\left({ }^{\circ} \mathrm{C}\right)\end{array}$ & $\begin{array}{c}\mathrm{Q} \\
\left(\mathrm{mW} / \mathrm{m}^{2}\right)\end{array}$ & $\begin{array}{c}\mathrm{Q} \\
\text { error } \\
( \pm \%)\end{array}$ \\
\hline FRHF42 & 1 & 5.97 & 72 & 20 \\
Site 762 & 99.4 & 14.5 & 79 & 25 \\
& 156.4 & 15.4 & & \\
Eendracht & 690 & 70.2 & 96 & 40 \\
FRHF45 & 1 & 4.39 & 41 & 20 \\
Site 763 & 52.4 & 7.1 & 64 & 15 \\
& 90.4 & 10.3 & & \\
Vinck & 147.4 & 12.1 & & 20 \\
\hline
\end{tabular}

Note: Near-surface measurements at heat-flow stations (Swift, 1990).

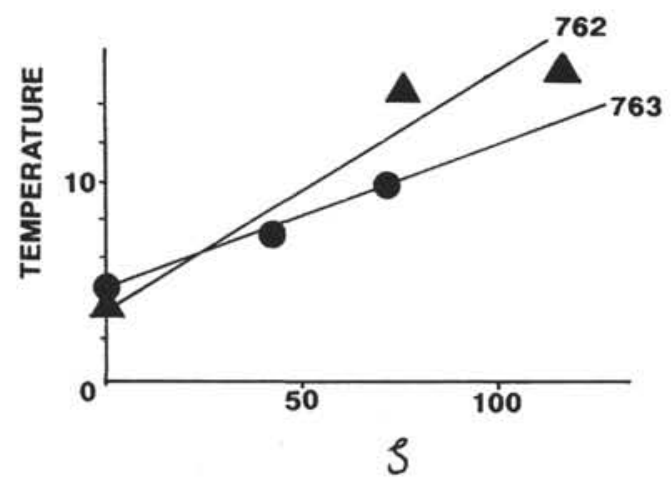

Figure 8. Bullard plot used to derived heat-flow levels for Sites 762 (triangles) and 763 (circles). Temperature in degrees Celsius.

trates that there is a reduction of heat flow with depth and that the heat-flow anomaly between the calculated present-day heat-flow level and the calculated heat flow from the geohistory analysis is of the order of $10 \mathrm{~mW} / \mathrm{m}^{2}$.

It is possible to associate the major differences between basement and surface heat-flow levels with times of rapid sedimentation. It seems that even though there has been a very low sedimentation rate only for the last 100 m.y., the upper crust has not fully recovered (thermally). This feature was first noted by Hutchison (1985); the cumulative sedimentation rate is just as important as the absolute rate at any one time in quantifying the overall thermal response of a sedimentary section.

\section{Site 762}

Because Site 762 is near the Eendracht exploration well it is possible to calculate the heat flow from two independent sources. The heat-flow level from Site 762 is $79 \mathrm{~mW} / \mathrm{m}^{2}$, compared to $96 \mathrm{~mW} / \mathrm{m}^{2}$ for the Eendracht well. The temperature field (Fig. 10) for Site 762 is also calculated to be markedly different from that of the Eendracht well. This difference can be explained as the result of the lack of accurate deep-temperature and thermal conductivity data, which highlights the difficulty in using shallow thermal data extrapolated to greater depths in thermal geohistory analysis. The Site 762 data, however, do allow a comparison between using sparse stratigraphic data (in the case of the Eendracht well) and a large data set for the shallow section. Comparison of the surface heat-flow anomaly plots between Site 762 and the Eendracht well (Figs. 11 and 12, respectively) shows that the well data are generally sufficiently dense to permit meaningful modeling of heat-flow anomalies caused by sedimentation.

\section{Site 763}

Site 763 is near the Vinck well location. A full comparison will be given in the following description of the Vinck exploration well. The temperature field for this location is shown in Figure 13. Like the previous analysis, it shows a pull-up in the isotherms as the sediment thickness increases. Sedimentation rates (Fig. 14) during the past may have been too small to greatly affect the subsurface heat flow. The only major anomaly is found at the inception of sedimentation. However, the cumulative sedimentation has been sufficient to cause and maintain a reduction in surface heat flow of about $8 \mathrm{~mW} / \mathrm{m}^{2}$.

\section{Vinck Exploration Well}

The surface heat flow from the BHT data for the Vinck well location is $65 \mathrm{~mW} / \mathrm{m}^{2}$, which is very close to the Site 763 value of $64 \mathrm{~mW} / \mathrm{m}^{2}$. The temperature field for the Vinck well (Fig. 15 ) is, however, markedly different from the temperature field of Site 763 (Fig. 13). This is wholly due to the different thermal conductivity profiles used. The thermal conductivity for all of the oil exploration wells is based on the porosity profile and lithologic type. On the other hand, thermal conductivity data exist for Sites 762 and 763 . The systematic error that seems to be coming out of the comparison between the ODP and commercial well data is that although it may be possible to match the surface heat flow, it is difficult to match the subsurface temperature profile, but heat-flow anomalies as a result of sedimentation seem to be the same. Sedimentation rates at the Vinck well (see Fig. 16) are markedly different from those previously discussed. Two periods of rapid sedimentation at 210 and 130 Ma caused a significant reduction in surface heat-flow levels.

Due to the problems of poor control on the thermal conductivity profile, the error in the BHT, and the fact that the BHT is derived at depths in excess of $1000 \mathrm{mbsf}$, it is difficult to compare the measured surface heat flow with a heat-flow value calculated for greater depths and extrapolated to the surface. The results from thermal geohistory analysis show that the fundamental assumption that heat flow is constant with depth is not valid in cases where there are transient phenomena, such as sedimentation. In a broader sense, vertical heat flow in a two- or three-dimensional framework is not conserved if there are large pore-fluid velocities or large lateral variations in the physical properties of the sediments. The poor comparison between the measured surface heat flow and the heat flow calculated from the thermal geohistory may 


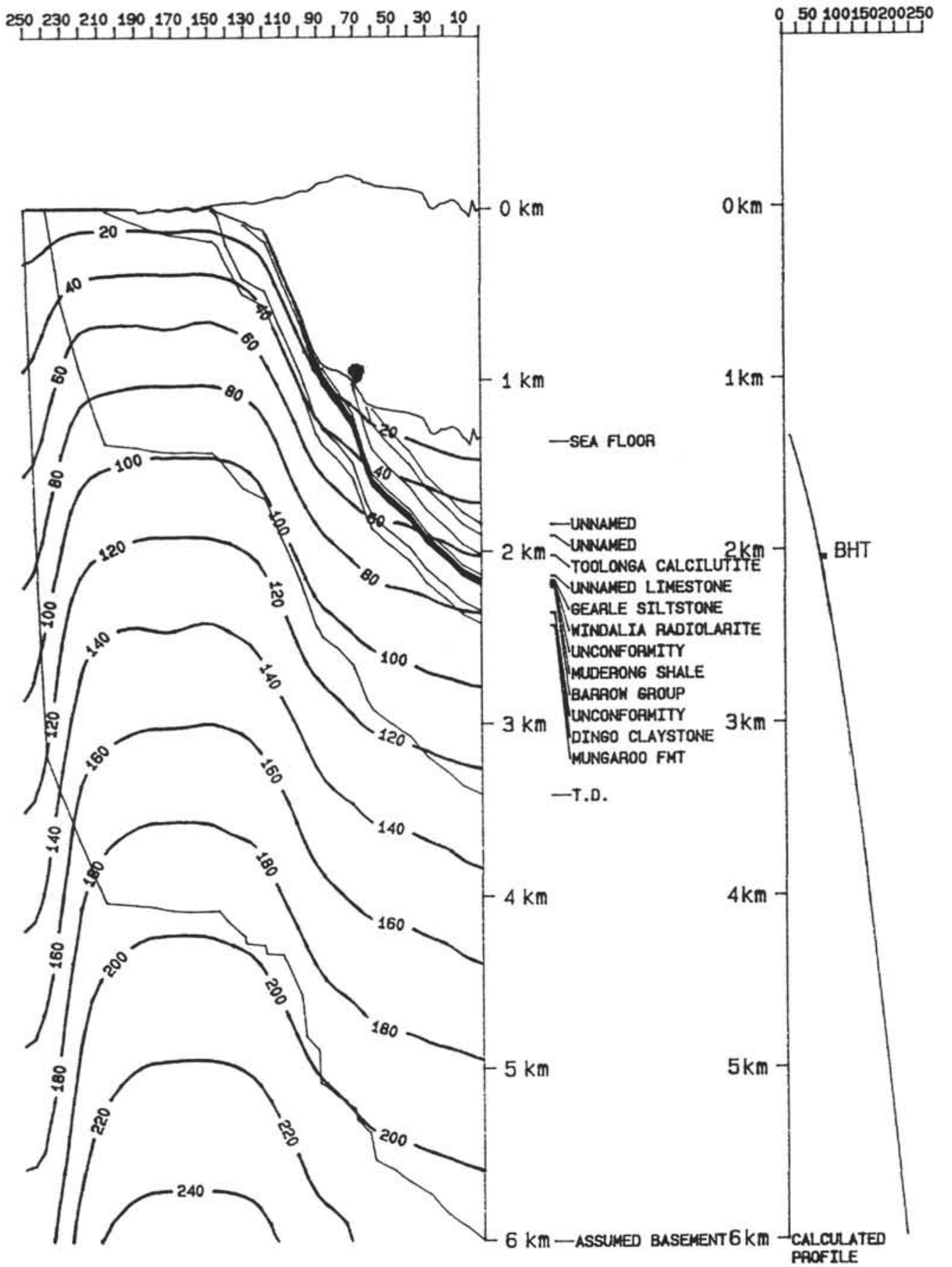

Figure 9. Time-depth-temperature $\left({ }^{\circ} \mathrm{C}\right)$ plot for the Eendracht exploration well. The plot on the right shows the calculated present-day profile and the measured BHT (square).

in part be also due to these effects. In other words, the one-dimensional (depth) aspect in thermal geohistory may be inadequate for explaining the surface heat flow, because the temperature data (BHT) for this analysis are too far from the surface. This is most probably the case at the Exmouth Plateau, as pore-fluid convection is suspected of causing a massive redistribution of subsurface heat flow. The main problem in using existing thermo-tectonic models is that paleo-heat flow is given in terms of surface heat flow (see the models of Sleep, 1971; Turcotte and Ahren, 1977; McKenzie, 1978; Royden and Keen, 1980; Le Pichon and Sibuet, 1981;
Beaumont et al., 1982; Bessis, 1986; Swift et al., 1987). As can be seen from the geohistory results, surface heat flow is disturbed by sedimentation. The problem now requires that the heat-flow level at the bottom boundary be specified. The depth to this bottom boundary, what heat-flow level to apply, and how both vary in time need to be determined.

Further, these models consider only conductive heat flow, whereas a complete model should incorporate convective heat transfer as well. These considerations are beyond the scope of this paper. As a reasonable first approximation, a constant basal heat flow at $20 \mathrm{~km}$ was assumed. 


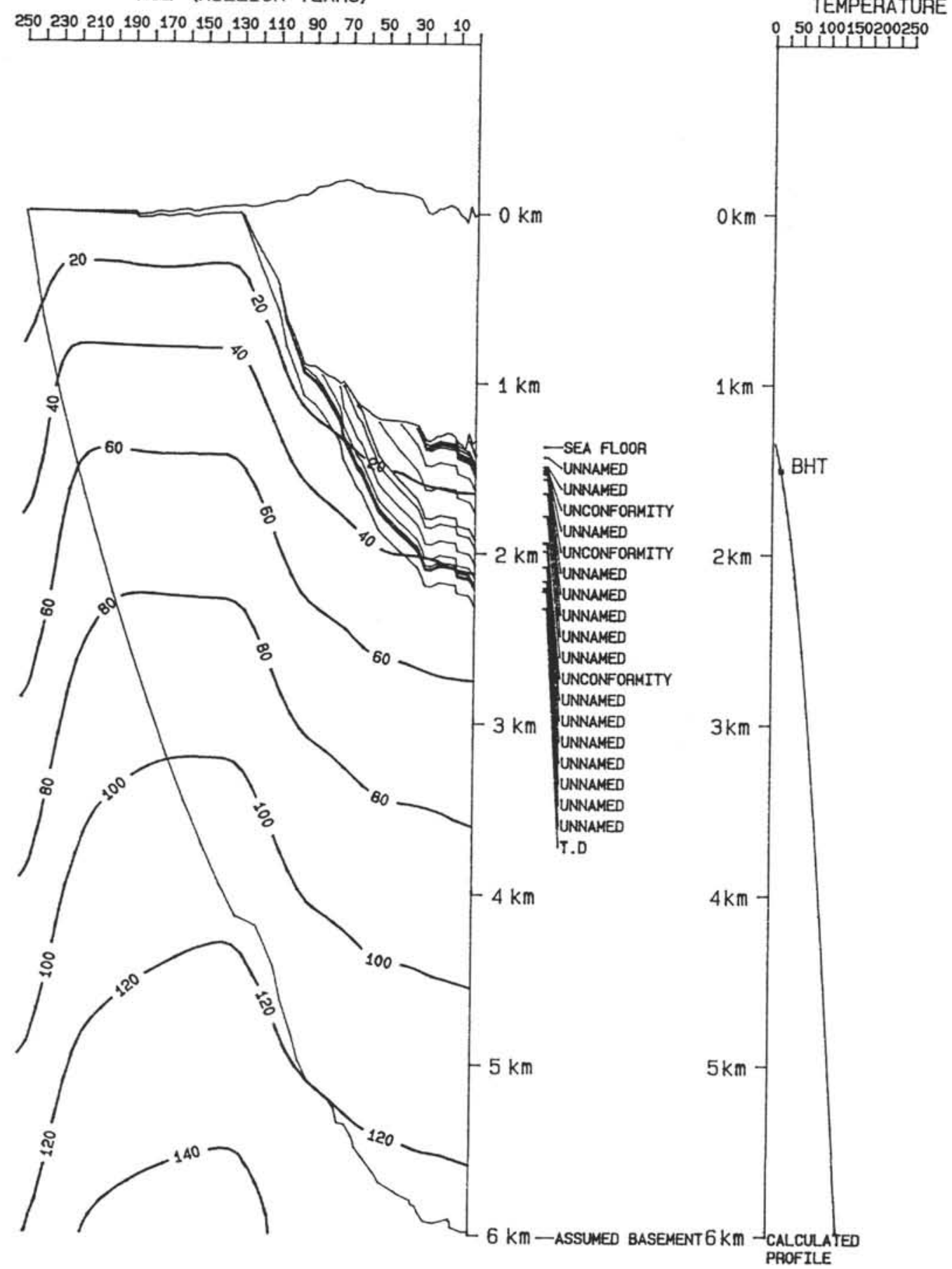

Figure 10. Time-depth-temperature $\left({ }^{\circ} \mathrm{C}\right)$ plot for Site 762 . The plot on the right shows the calculated present-day profile and the measured BHT (square).

The one avenue of geohistory analysis that is useful is the observation that the surface heat-flow values over the Exmouth Plateau should consistently be about $12 \%$ lower than the basal heat flow. This provides a correction factor for the effect of sedimentation that reduces the surface heat flow. It is surprising that the correction factor is as high as $10 \%$, considering that the region has been starved of sediment since the Cretaceous. The magnitude of the correction factor is probably an overestimate because the thermal geohistory analysis is only one (spatial) dimensional.

\section{CONCLUSIONS}

At two localities on the Exmouth Plateau there now exist heat-flow determinations based on temperature measurements made at three different depths using different measurement methods (Table 1).

There is a good correspondence between at least two of the heat-flow levels at each locality. On face value it appears that heat flow is increasing with depth at both locations. The heat flow from Site 762 is higher at all levels compared with that at 


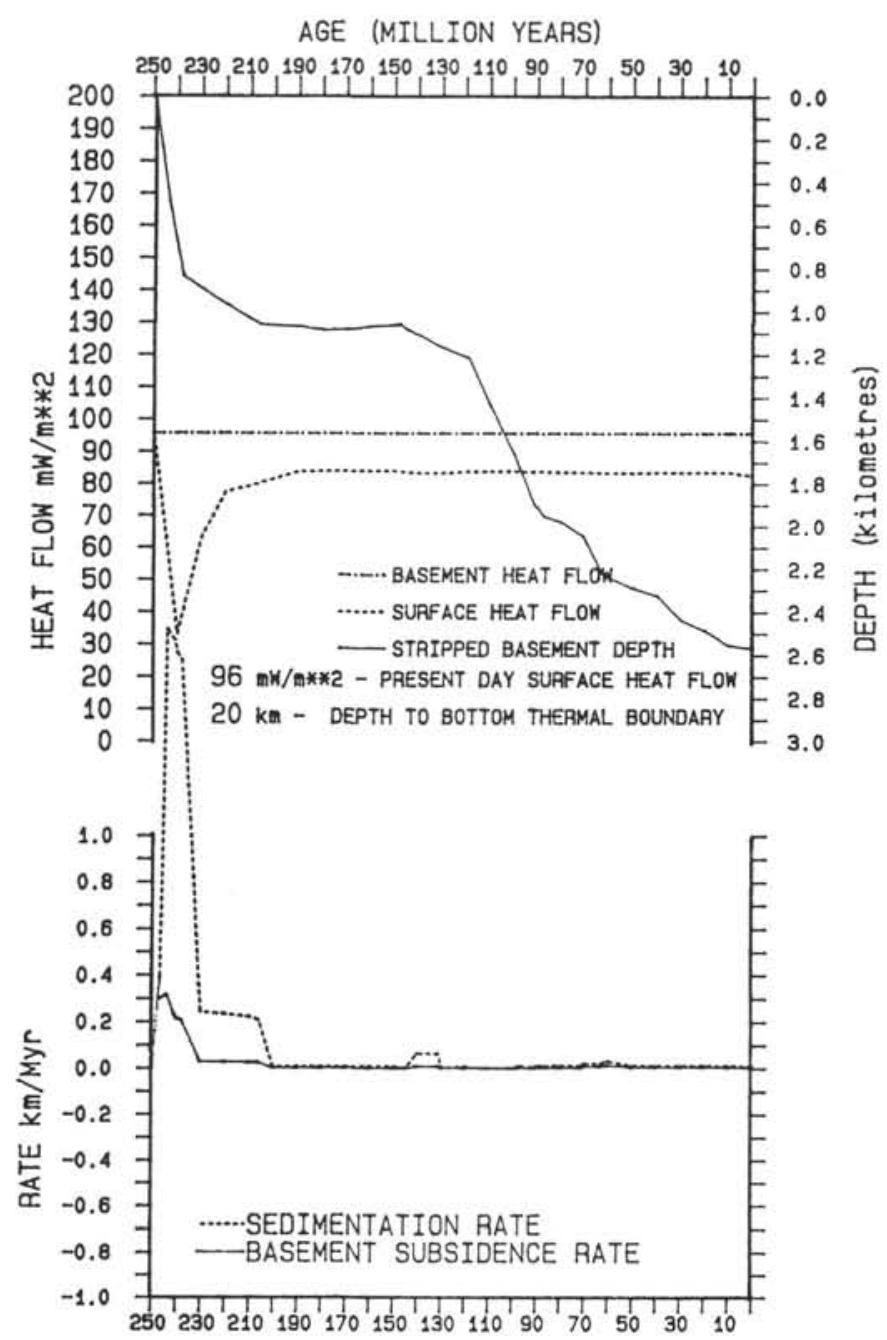

Figure 11. Temporal variation of the stripped basement depth, basement heat flow, surface heat flow, sedimentation/erosion rates, and basement subsidence/uplift rates for the Eendracht exploration well.

Site 763, which matches the higher temperatures at equivalent levels at Site 762 than at Site 763. This is to say that the vertical geothermal gradient at Site 762 is greater than at Site 763. This means that there is a horizontal temperature gradient between the two sites. Consequently, given sufficient permeability, pore fluid will flow as a result of natural convection because there will be a pore-fluid density gradient.

The most problematic heat-flow data are those derived from the thermal geohistory analysis of the oil exploration wells. This problem arises from the assumptions regarding the thermal conductivity at depth and errors in the BHT. Also, the geohistory method shows that there should be an increase in heat flow with increasing depth in response to sedimentation and compaction effects. This effect together with the suspected error in each measurement (Table 1) means that it is not possible to conclusively determine any change in heat flow with depth that is due to pore-fluid convection.

From the new heat-flow data from Sites 762 and 763 it is not possible to invoke any changes in the thermal histories of the region. Thermal geohistory analysis of Sites 762 and 763 shows that subsurface paleo-heat-flow levels are affected by sedimentation. However, paleo-heat-flow levels are too difficult to uniquely determine if, as is hypothesized, pore-fluid
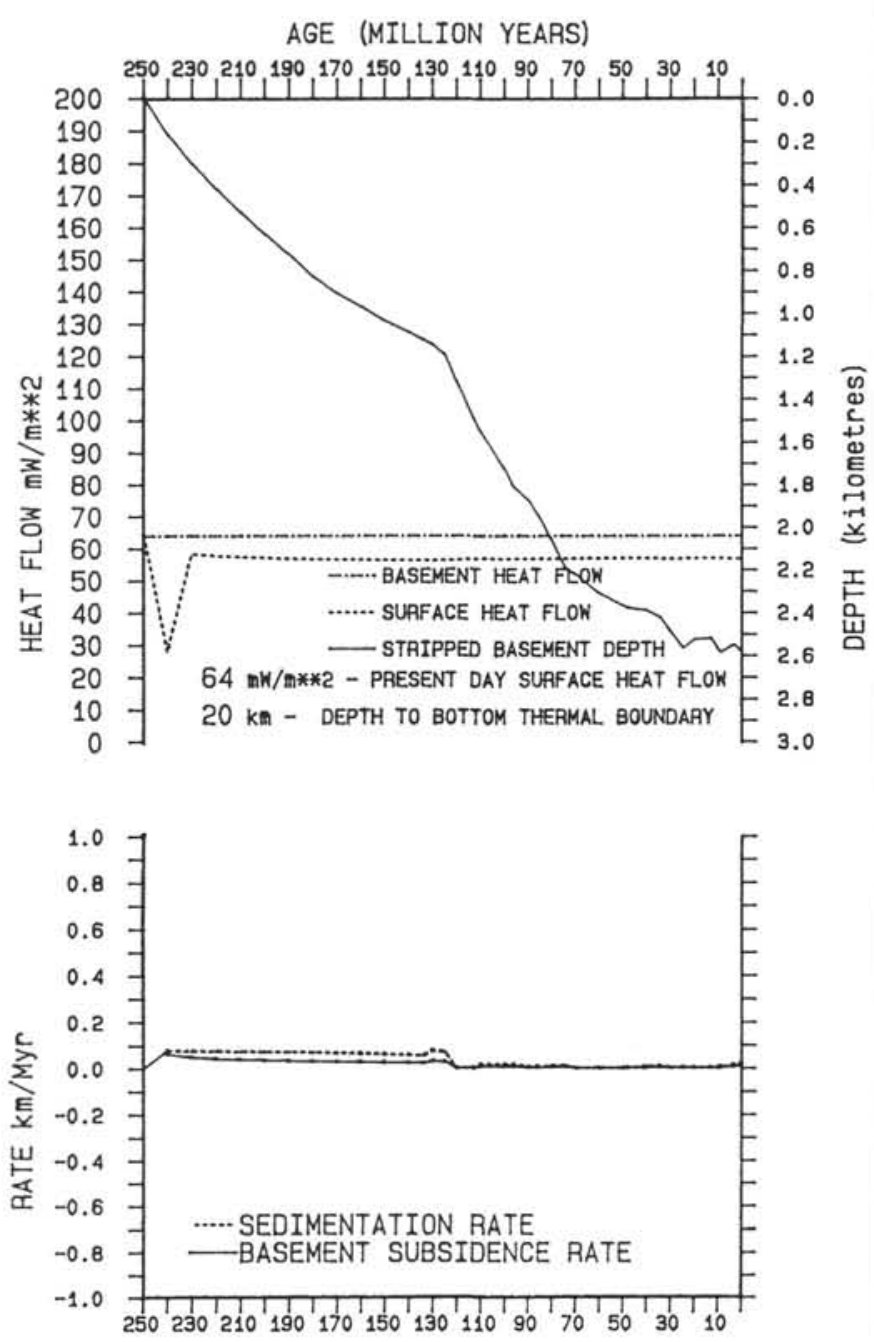

Figure 12. Temporal variation of the stripped basement depth, basement heat flow, surface heat flow, sedimentation/erosion rates, and basement subsidence/uplift rates for Site 762 .

convection is occurring on a regional scale at Exmouth Plateau.

The heat-flow data from Sites 762 and 763, however, do support the finding that there is a lateral variation of heat flow across the Exmouth Plateau. This, in turn, requires that natural pore-fluid convection causes this variation-or, on the other hand, has resulted because of it. If basal heat flow has been higher in the past, then convection may have been more vigorous. However, the vitrinite reflectance data would suggest that pore-fluid convection has been occurring only since the early Tertiary.

\section{REFERENCES}

Anderson, R. N., Langseth, M. G., and Sclater, J. G., 1977. The mechanisms of heat transfer through the floor of the Indian Ocean. J. Geophys. Res., 82:3391-3409.

Barber, P. M., 1982. Paleotectonic evolution and hydrocarbon genesis of the central Exmouth Plateau. APEA J., 22:131-144.

Beaumont, C., Keen, C. E., and Boutilier, R., 1982. On the thermal evolution of rifted continental margins: comparison of models and observations for the Nova Scotian margin. Geophys. J. R. Astron. Soc., 70:667-715.

Bessis, F., 1986. Some remarks on the study of subsidence of sedimentary basins. Application to the Gulf of Lions margin, western Mediterranean. Mar. Pet. Geol., 3:37-63. 
Bullard, E. C., 1954. The flow of heat through the floor of the Atlantic Ocean. Proc. R. Soc. London A, 222:408-429.

Burne, R. V., and Kantsler, D., 1977. Geothermal constraints on the hydrocarbon potential of the Canning Basin, Western Australia. BMR J. Aust. Geol. Geophys., 2:271-288.

Choi, D. R., Stagg, H.M.J., and Scientific Party, 1987. Rig Seismic research cruise 6: Northern Australia heat flow post cruise report. Rep.-Bur. Miner. Resour., Geol. Geophys. (Aust.), 274.

Cook, A. C., and Kantsler, A. J., 1980. The maturation history of the epicontinental basins of Western Australia. Tech. Bull.-U. N. Econ. Soc. Comm. Asia Pac., Comm. Co-ord. Jt. Prospect. Miner. Resour. South Pac. Offshore Areas, 3:171-195.

Cook, A. C., Smyth, M., and Vos, R. G., 1985. Source potential of Upper Triassic fluvio-deltaic systems of the Exmouth Plateau. APEA J., 25:204-215.

Cull, J. P., and Conley, D., 1983. Geothermal gradients and heat flow in Australian sedimentary basins. BMR J. Aust. Geol. Geophys., 8:329-337.

Guidish, T. M., Kendall, C.G.St.C., Lerche, I., Toth, D. J., and Yarzab, R. F., 1985. Basin evaluation using burial history calculations: an overview. AAPG Bull., 69:92-105.

Haq, B. U., von Rad, U., O'Connell, S., et al., 1990. Proc. ODP, Init. Repts., 122: College Station, TX (Ocean Drilling Program).

Hutchison, I., 1985. The effect of sedimentation and compaction on oceanic heat flow. Geophys. J. R. Astron. Soc., 82:439-459.

Kopsen, E., and McGann, G., 1985. A review of the hydrocarbon habitat of the eastern and central Barrow-Dampier Sub-Basin, Western Australia. APEA J., 25:154-175.

Langseth, M. G., and Taylor, P. T., 1967. Recent heat flow measurements in the Indian Ocean. J. Geophys. Res., 72:6249-6260.

Le Pichon, X., and Sibuet, J. C., 1981. Passive margins: a model of formation. J. Geophys. Res., 86:3708-3720.

Lister, G. S., Etheridge, M. A., and Symonds, P. A., 1986. Detachment faulting and evolution of passive continental margins. Geology, 14:246-250.

McKenzie, D., 1978. Some remarks on the development of sedimentary basins. Earth Planet. Sci. Lett., 40:25-32.

Nicholas, E., Rixon, K., and Haupt, A., 1980. Uncorrected geothermal map of Australia. Bur. Miner. Resour. Geol. Geophys. Rec., 1980/66, unpubl.

Royden, L., and Keen, C. E., 1980. Rifting processes and thermal evolution of the continental margin of eastern Canada determined from subsidence curves. Earth Planet. Sci. Lett., 51:343-361.
Sleep, N. H., 1971. Thermal effects of the formation of Atlantic continental margins by continental breakup. Geophys. J. R. Astron. Soc., 24:325-350.

Swift, B. A., Sawyer, D. S., Grow, J. A., and Klitgord, K. D., 1987. Subsidence, crustal structure, and thermal evolution of the Georges Bank Basin. AAPG Bull., 71:702-718.

Swift, M. G., 1990. Heat flow studies of the Exmouth Plateau, offshore North West Australia [Ph.D. thesis]. Australian National Univ.

in press. Heat flow modelling: a generalized two dimensional diffusive and convective numerical model for the Exmouth Plateau, offshore North West Australia. Tectonophysics.

Swift, M. G., Stagg, H.M.J., and Falvey, D. A., 1988. Heat flow regime and implications for oil maturation and migration in the offshore northern Carnarvon Basin. In Purcell, P. G., and Purcell, R. R. (Eds.), The North West Shelf, Australia. Proc. Pet. Explor. Soc. Aust. Symp., 539-551.

Turcotte, D. T., and Ahren, J. L., 1977. On the thermal subsidence history of sedimentary basins. J. Geophys. Res., 82:3762-3766.

Veevers, J. J., and Cotterill, D., 1978. Western margin of Australia: evolution of rifted arch system. Geol. Soc. Am. Bull., 89:337-355. 1979. Western margin of Australia: a Mesozoic analogue of the East Africa rift system. Geology, 7:713-717.

Von Herzen, R. P., and Langseth, M. G., 1965. Present status of oceanic heat flow measurements. Phys. Chem. Earth., 6:365-407.

Von Herzen, R. P., and Maxwell, A. E., 1959. The measurement of thermal conductivity of deep-sea sediments by a needle probe method. J. Geophys. Res., 65:1557-1563.

Voorhoeve, H., and Houseman, G., 1988. The thermal evolution of lithosphere extending on a low-angle detachment zone. Basin Res., 1:1-9.

Williamson, P. E., Swift, M. G., Kravis, S. P., Falvey, D. A., and Brassil, F., 1990. Permo-Carboniferous rifting of the Exmouth Plateau region, Australia: an intermediate plate model. In Pinet, B., and Bois, C. (Eds.), The Potential of Deep Seismic Profiling for Hydrocarbon Exploration: Paris (Editions Technip), 235-248.

Date of initial receipt: 17 July 1990

Date of acceptance: 12 February 1991

Ms 122B-118 


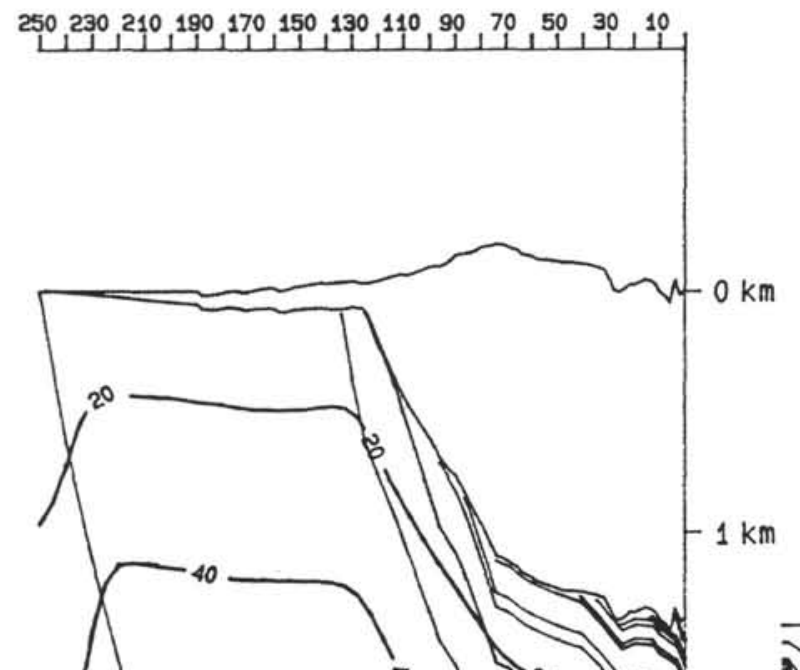

TEMPERATURE

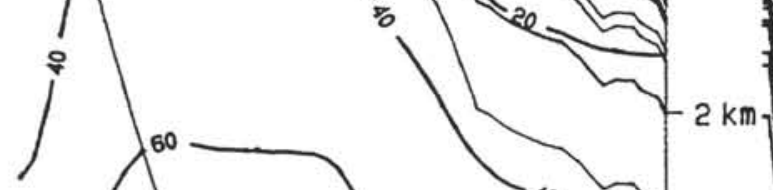

-SEA FLOOR

UNCONFOAMITY

UNNAMED

UNNAMED

UNNAMED

UNNAMED

UNCONFORMITY

O 5010015020025

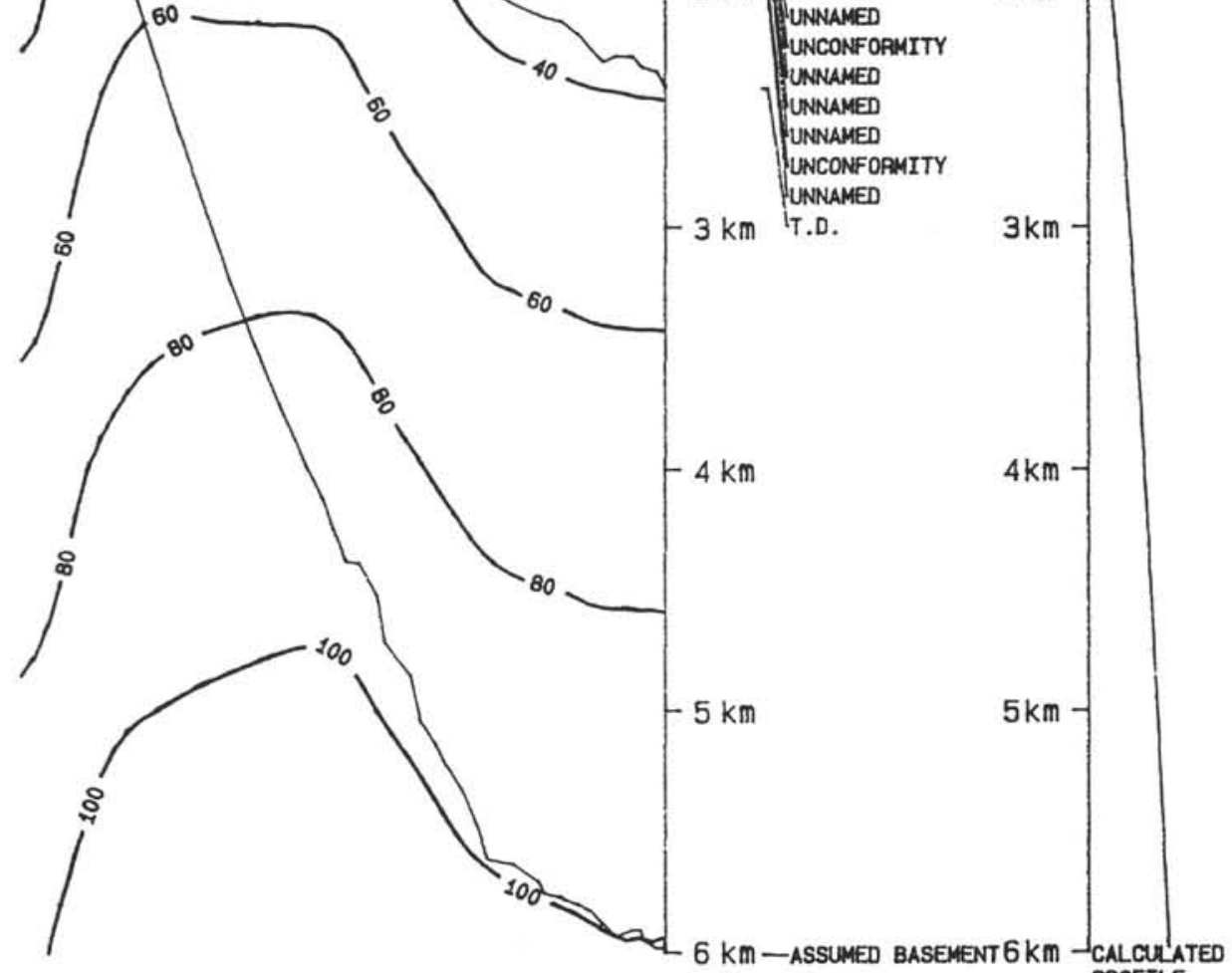

PAOFILE

Figure 13. Time-depth-temperature $\left({ }^{\circ} \mathrm{C}\right)$ plot for Site 763 . The plot on the right shows the calculated present-day profile and the measured BHT (square). 

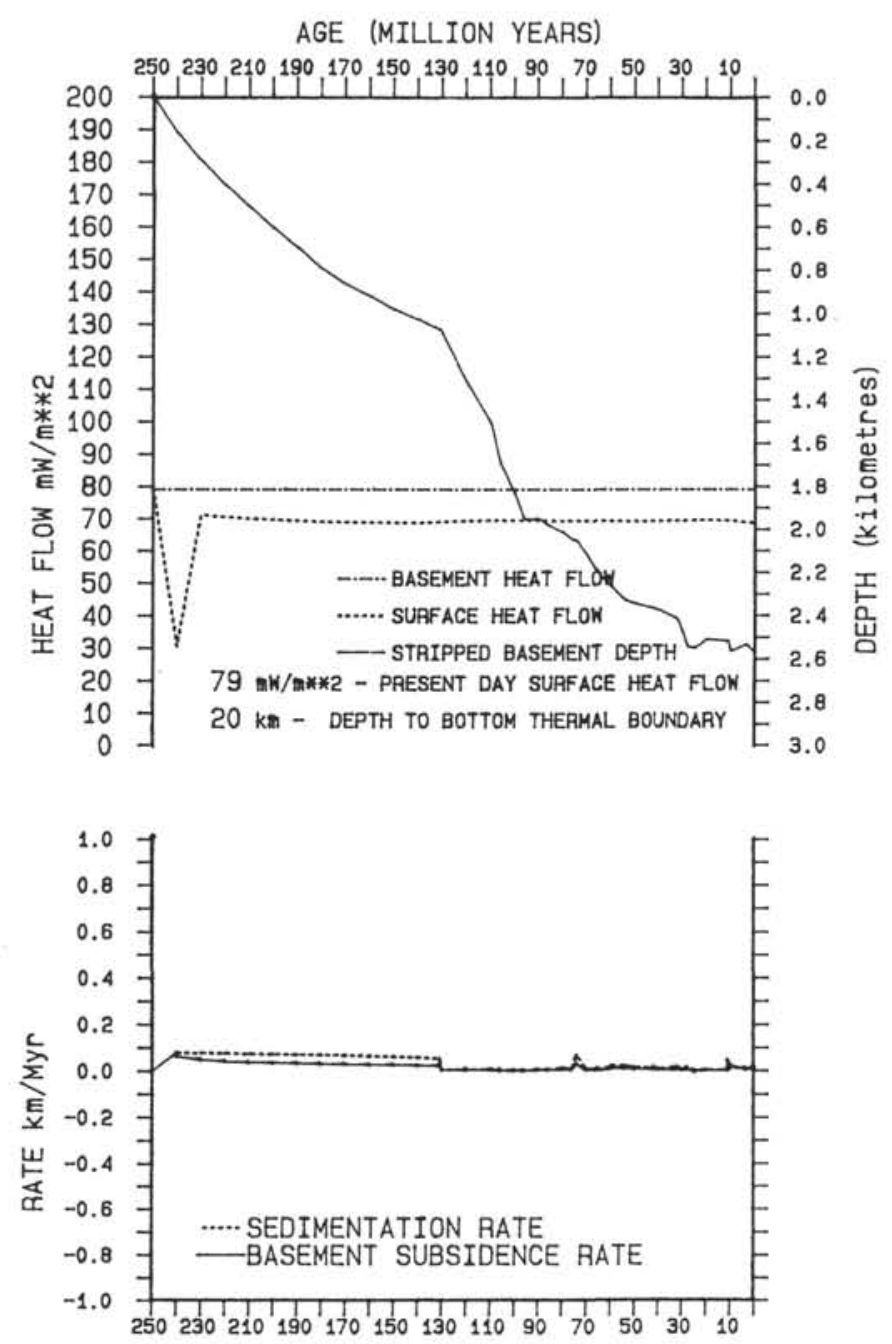

Figure 14. Temporal variation of the stripped basement depth, basement heat flow, surface heat flow, sedimentation/erosion rates, and basement subsidence/uplift rates for Site 763 . 


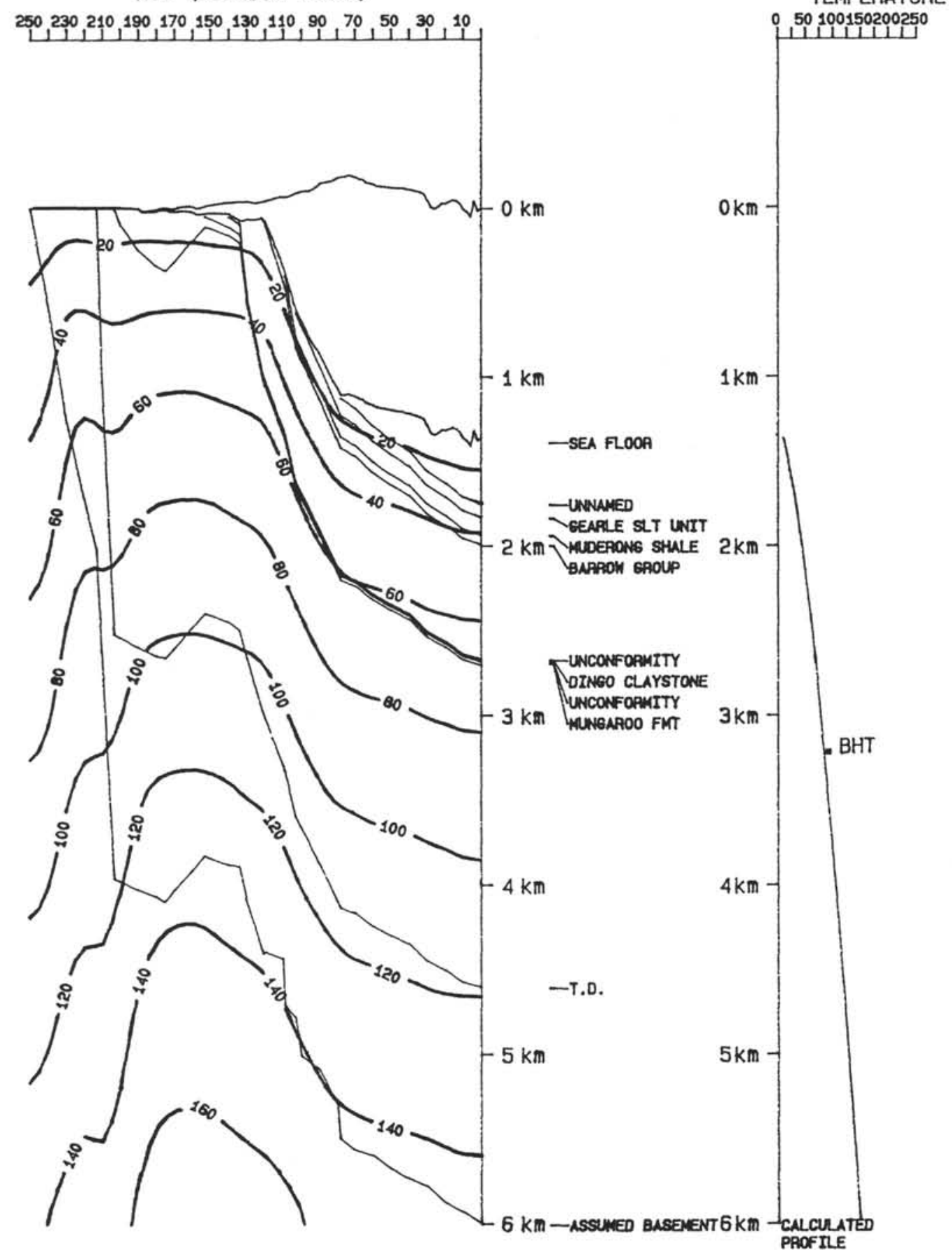

Figure 15. Time-depth-temperature $\left({ }^{\circ} \mathrm{C}\right)$ plot for the Vinck exploration well. The plot on the right shows the calculated present-day profile and the measured BHT (square). 


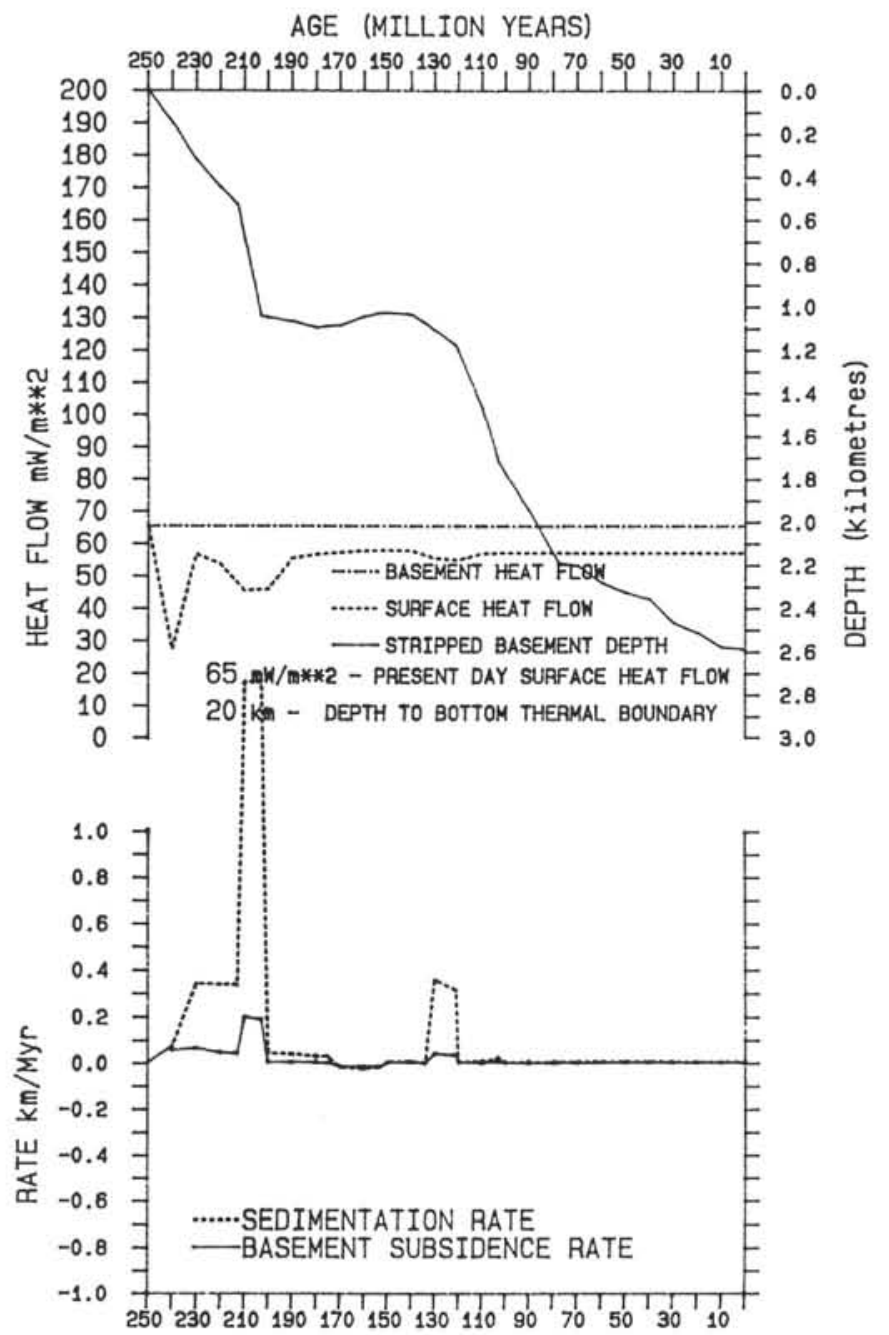

Figure 16. Temporal variation of the stripped basement depth, basement heat flow, surface heat flow, sedimentation/erosion rates, and basement subsidence/uplift rates for the Vinck exploration well. 